\title{
From Maltese phonology to morphogen- esis: A tribute to David Cohen
}

\begin{abstract}
On 9 March 2013, David Cohen passed away at the age of 90 . He was a great scholar and a man of perfect scientific integrity. He was also my supervisor when I was preparing my PhD thesis on Maltese in the late 1980's. I owe him a lot scientifically and professionally. This is why I decided to take the opportunity of the fourth Ghilm meeting in Lyon to pay him a tribute, by recalling some of his works and influence on Maltese linguistics, even if this tribute is more modest than the one he deserves, but which he already received through a monumental Festschrift volume (Lentin \& Lonnet 2003) and several prestigious prizes.
\end{abstract}

Keywords: Maltese, phonology, synchrony, diachrony, comparative linguistics, Arabic dialectology

Martine Vanhove: French National Centre for Scientific Research, Langage, Langues et Cultures d'Afrique Noire (LLACAN, UMR 8135), 7, rue Guy Môquet, 94801 Villejuif cedex, France.E-mail: vanhove@vjf.cnrs.fr

\section{Introduction}

David Cohen dedicated a great deal of his research to historical and comparative linguistics in the domain of Semitic and Afroasiatic languages (which he kept on calling "Hamito-Semitic", because it was no less scientifically grounded than "Afroasiatic"). It is on this phylum that he entrenched his theoretical and general questioning about the human capacity of language and about how and why languages change and are what they are. He leaves his imposing Dictionnaire des racines sémitiques, whose first volume was published in 1970, unfinished. Fortunately he managed to publish the first ten volumes and hopefully his collaborators from volume 3 onwards will complete his work. One of his most important contributions to research in the domain of historical and comparative linguistics concerns the evolution of aspectual systems and the renewal of verbal systems in general. The book, La phrase nominale et l'évolution du système verbal en sémitique. Etude de syntaxe historique, written as a Thèse d'Etat in the mid-1970's and published in an abridged version in 1984, goes far beyond 
what the title suggests. It concerns in fact three branches of the Afroasiatic languages, Semitic, Cushitic and Egyptian. He expanded his views to a crosslinguistic perspective and developed what he was reluctant to call a theory of aspect in L'aspect verbal (1989). This book also includes his first published thoughts on the role of auxiliaries and verbal periphrastic constructions in general in the renewal of verbal systems (if one excepts his annual Rapports sur les Conférences de l'Ecole Pratique des Hautes Etudes, IV section, Sciences Historiques et philologiques, in particular that of the academic year 1982-83 and the section on "Les auxiliaires dans l'expression périphrastique du parfait"), within the larger framework of "morphogenesis", a term more adequate to his comparative research which was enfolding not only processes of reanalysis, what is known as grammaticalization today (cf. e.g. Heine 1993), but other processes of language change such as polarity, analogy and language contact.

It is not the aim of this article to give a thorough account of David Cohen's contribution to linguistics since such an attempt would lead far beyond Maltese linguistics. So, in addition, I will just recall very briefly his major contributions to what is traditionally termed as "Arabic dialectology" and his three volumes on the Arabic varieties of Tunis (Jewish variety, Cohen 1964-1975) and Mauritania (Cohen 1963), as well as his pioneer works on computational linguistics (Cohen 1970) and language pathology and aphasia (Cohen et al. 1963 and 1965). A detailed bibliography was published in his Festschrift volume (Lentin \& Lonnet 2003).

In the domain of Maltese linguistics, David Cohen's contributions are both direct and indirect.

I will start with and mainly concentrate on the direct ones, which concern phonology from a synchronic and diachronic viewpoint, and put them in perspective with a very limited number of previous and further works of other linguists, given the space constraint.

\section{The phonology of Maltese}

After a note on the vocalic system of Maltese (Cohen 1957-1960), David Cohen wrote a fundamental paper on Maltese phonology, within the structuralist theoretical framework of the time as well as within a comparative perspective with Arabic from which the Maltese language stemmed. This paper was also important and a highly valuable input for sound research on Maltese phonology in the various theoretical frameworks that followed, although this is not always acknowledged in the bibliographies, probably because it was written in French. 
"Le système phonologique du maltais. Aspects synchroniques et diachroniques", was first published almost half a century ago, in 1966, in the third issue of the then newly founded Journal of Maltese Studies, and was reprinted in his book Etudes de linguistique sémitique et arabe in 1970. It is an extension of a paper he presented in 1965 at the Second International Congress of Dialectology, which was held in Marburg, and was published in the Proceedings of the conference in 1967 under the title "Contribution à la phonologie diachronique du maltais". In order to write his phonology of Maltese, David Cohen used two different sources, the first one was Aquilina's late 1930s description of Maltese, which was published in 1959 (The structure of Maltese. A Study in mixed grammar and vocabulary), and Hans Stumme's Maltesische Studien. Eine Sammlung prosaischer und poetischer Texte in maltesischer Sprache published in 1904. He was only able to check his phonetic observations on a short sample of recordings that were kindly sent to him by J. Aquilina. Of course, for Stumme's data he had to rely on his phonetic transcriptions of the various Maltese varieties he illustrated, since phonology was only emerging at that time. Regarding Aquilina, his structural description, which he claimed was "never meant to fall within the specific category of any particular school of linguistics" (Aquilina 1973: iv) nevertheless acknowledges the influence of the theoretical framework developed by John Rupert Firth (1957) at the SOAS in Great Britain before World War II. His phonetic and phonological description is thus influenced by this theory. It is also heavily influenced by some etymological issues: the phonology section was subdivided into two sub-sections, viz. Semitic and non-Semitic Maltese, a common practice among scholars of the Maltese language in the first half of the 20th century (cf. e.g., Sutcliffe 1936). Aquilina provided a thorough study of ghajn regarding its vocalic and consonantal allophones. Still in the so-called "Semitic" part of Maltese, nothing was mentioned about the influence of the back and so-called "emphatic" consonants (i.e. pharyngealized) on the vocalic system, which David Cohen was the first to explain in 1965, roughly at the same time as Cowan (1966) who made a similar and probably independent analysis, and who published his paper in the same issue of the Journal of Maltese Studies as Cohen's (1966).

\subsection{The phonological status of $g \hbar$ and $h$}

I won't recall here the details of David Cohen's synchronic phonology, which are well established now and uncontroversial, even if Maltese of course has evolved over the last 50 to 100 years, but I will concentrate instead on issues which are particularly important in a comparative perspective. I will start first 
with his arguments concerning the phonological status of ghajn and $h$, for which he borrowed the adjective "virtual" from Stumme (1904), the first scholar to briefly discuss in a short note the unusual status of the various allophones in the different dialects of Maltese of what he recognized as developments of three Arabic phonemes, $\varsigma, \dot{g}$ and $h$.

David Cohen states first that the treatment of ghajn and $h$ as phonemes in the Maltese grammars are ultimately based on morphological grounds. In what follows, I will just translate ${ }^{1}$ and summarize the main lines of his argumentation.

1. The C $\breve{v} C a$ pattern of Perfective verbs in the 3rd person singular masculine such as rema 'he threw' and sema' 'he heard', which have two distinct paradigms for 3 rd persons singular feminine and plural in the Perfective (the paradigms $^{2}$ are given in Cohen 1970: 130):

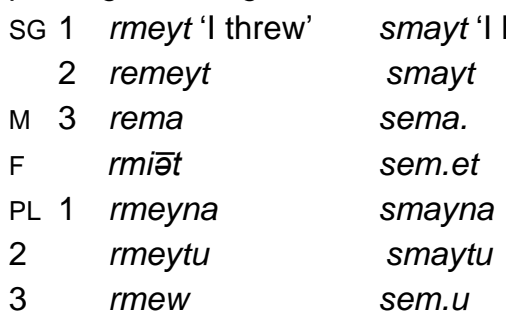

and of the plural forms in the Imperfective:

narmu, etc. nesm.ew, etc.

2. The existence of a verb class whose paradigms go against the general principles of the syllabic structures and of the stress rules of Maltese: yo?ó.du 'they will sit', yelá.bu 'they will play' vs. the "normal" forms níktbu 'we'll write' or nizíl?u 'we'll slide'.

3. The existence of forms with alternating allomorphs, namely the pharyngeal $\hbar$ in absolute final position or $\varnothing$ (or a pharyngealisation and/or lengthening of the adjacent vowel) before enclitics, e.g. biäh 'he sold', nbélek or nbé\%k 'I'll sell to you'. And the existence of other forms with the reverse allomorphic pattern, a vowel in absolute final position, and the pharyngeal $\hbar$ before the enclitic pronouns of 3 rd person singular feminine and 3rd person plural, e.g.

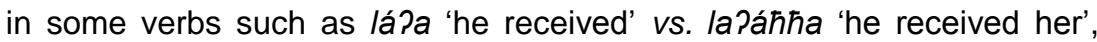

1 Most parts of what follows are mere translations or adaptations of David Cohen's articles written in French, in order to make them more easily accessible to those who are not familiar with the French language.

2 D. Cohen's transcriptions are given as they appear in his article, minus the obvious typos. 


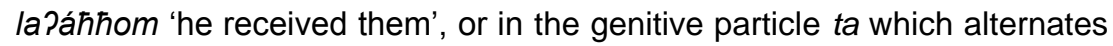

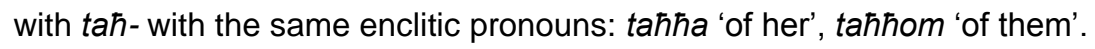

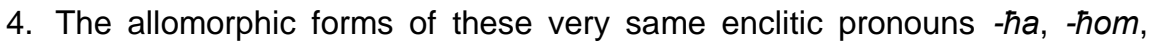
which in other phonetic contexts are not pronounced with an initial consonant, but are written in the Maltese spelling system with an $h$ described as quiescent in grammars and which presents a series of forms with special paradigms, e.g. verbs such as $f e^{\circ} \mathrm{em}$ 'he understood' where the stem alternates between $\mathrm{CeC}$ before a vowel, $\mathrm{CiC}$ before a consonant.

5. The existence of a particular factitive pattern for this verb type with a long vowel instead of a geminated medial consonant: fī̄em 'he made understand'.

These particular features were discussed at length and with great details within the framework of generative linguistics by Michael K. Brame (1972) a few years later, in an article entitled On the abstractness of phonology: Maltese $\mathrm{S}$. Brame does not mention David Cohen's paper (neither Aquilina's description, nor Stumme's work). Nevertheless, he arrives at the very same conclusions as David Cohen's (and Cowan) by proposing a set of rules typical of the generative approach of the time, some of them related to classes of consonants, in order to prove the necessity to postulate, in some instances, an underlying representation that deviates from and is not represented in the phonetic surface alternations. He posits the abstract existence of a fricative pharyngeal phoneme $\varsigma$, but leaves aside one logical consequence of his approach, the possibility of a second abstract laryngeal phoneme $h$ whose allophones he does not deal with in his paper, and which only partly overlap with those of ghajn.

In addition to the above mentioned morphological arguments, David Cohen brings further arguments of a sociolinguistic and comparative nature. He explicitly mentions that morphology is not in itself a decisive argument that would make it possible to decide in favor of a "full" phoneme, but that the problem is crucial enough to be taken into account if one does not want to distort the language phonological system (which Peter Schabert (1976) did to some extent in his description of the diphthongs of two Maltese varieties, even though he mentions David Cohen's work). He first refers to the fact that the non-articulation of $g \hbar$ and $h$ is not a general phenomenon in all Maltese varieties. The speakers who did not pronounce them were in contact with others who, in the first half of the 20th century, did have various allophones of the virtual phoneme from a simple hiatus between two vowels to pharyngeal and laryngeal consonants. Thus the existence of the virtual phoneme was "felt" by all speakers, at least in a good number of forms. This situation reminded him of a similar one: that of the Arabic variety of the Jewish population of Tunis (of which he was a native 
speaker) and which he had described in two volumes (Cohen 1964-1975). In this Arabic variety, the laryngeal phoneme was not pronounced as such, but was existing in the contact variety spoken by the Muslims, maintaining the awareness of a kind of "virtual" phoneme, a mere phonemic quantity, with various contextual allophones, including vowel lengthening, a variant still found in today's Maltese.

From a comparative point of view D. Cohen also mentions, as of particular importance, the partial assimilation of verbs whose third root consonant is a pharyngeal to the paradigm of verbs ending in a semi-vowel. His argument, based on analogy, runs as follows: where the semi-vowel was represented by an autonomous phonetic quantity, the conjugation could align with that of verbs with a pharyngeal consonant, e.g. the singular 1st and 2 nd persons of the Perfective, where *qata $t$ could be assimilated to ramayt in the form of Patayt. But when the form taken by the last semi-vowel of the stem was fused with the flectional morpheme, verbs with a final pharyngeal maintained a phonemic quantity realised as a vowel before the flectional morpheme, e.g. ya?tew as opposed to yarmu. His conclusion was that the various cognates of the Arabic pharyngeals and laryngeal were, in Maltese, in a transitory phase of an already advanced phonological shift. D. Cohen considered that this evolution would most probably lead to their total disappearance. A fact well known of Maltese linguists, and that teachers of Maltese keep pointing at as orthographic "mistakes" made by students of Maltese when they align their paradigms with that of other root types, in particular the mistakes that lead to consonant clusters similar to the affricate consonants of Maltese $\dot{c}$ and $z$.

David Cohen goes on by explaining that this virtual phoneme, even if not realized in a stable way, keeps having an influence on contextual elements. $\mathrm{He}$ concludes, in order to account for all the phenomena described, in favor of the existence of a phoneme which he represents, unlike M. K. Brame, by abstract symbols, i.e. "." or "“", which cannot be associated with any particular phonetic realization. The complementary distribution of the various allophones he proposes is not exhaustive because of the limited documentation he has had access to, but is accurate for the Maltese language of the first half of the 20th century.

\subsection{The influence of "emphatic" and back consonants on the vocalic system}

The second important point in David Cohen's article concerns the effects of the partial loss and fusion of the back and "emphatic" consonants on the synchronic 
vocalic system. As is now well known, Maltese lost, probably at an early stage, all the emphatic consonants that are still preserved in most Arabic varieties. They were fused with the corresponding non-emphatic phonemes.

One result of David Cohen's research on the vocalic system is the discovery that, like most Maghribi Arabic dialects, Maltese had shared the innovation of an emphatic flap $r$, which will be discussed further below. His reconstruction is based on the evidence of the vocalic system, whose phonology he first describes before arguing about diachronic evolutions.

Standard Maltese has four short phonological vowels (in a structuralist sense, i.e. when accented, $u$ occurring only in unstressed position), $a, e, i, o$ (and probably now a fifth one, $u$, because of the massive borrowings from Italian and English that are still going on). It also has six long vowels, which at the time of his description were the five monophthongs $\bar{a}, \bar{I}, \bar{o}, \bar{e}, \bar{u}$, and one diphthong $i \bar{\partial}$, which only occur in stressed position. Note that the existence of the diphthong was not led by the orthography as Alexander Borg (1976: 200, n. 14) claims in his paper about the imaala in Maltese, but that it did exist, and still does, in some Maltese varieties, although not in Standard Maltese of today as described by e.g., Albert Borg and Marie Azzopardi-Alexander (1997). Anyway, what David Cohen clearly showed, and which ended (or almost...) the speculations of a possible oriental origin of the Arabic ancestor of Maltese which were initiated by Stumme's work, is that this system is due to several historical, phonological and sociolinguistic factors. David Cohen's (partial) explanation of the actual system can be partially summarized as follows:

(i) the fusion, at an early stage of the Maltese development, of the two short vowels $i$ and $a$, as is the case in many Maghribi varieties, and their massive reintroduction under the pressure of intensive contact with a foreign and genetically unrelated group of languages, Italian and Sicilian;

(ii) the role of stress;

(iii) the role of the syllabic structure;

(iv) what he called a "shift of distinctivity" from consonantal features to vocalic quality and quantity;

(v) borrowings from Italian and Sicilian.

If the last three factors are widely accepted and have been developed, in different theoretical frameworks (e.g. Gilbert Puech (1979 and 1994) and Alexander Borg (1976, 1977 and 1996) on the various phonemic evolutions and diphthongizations of short and long vowels and on the imaala in various varieties of Maltese, or in my own work with Antoinette Camilleri on the dialect of Mgarr (Camilleri \& Vanhove 1994)), the two first factors seem to be overlooked some- 
time when one reads, even today sometimes, arguments concerning the filiation of Maltese with one or the other of the two major geographic divisions of Arabic dialects.

Let us examine now in more details David's Cohen diachronic argumentation.

a. The short vowel $\breve{e}$, is a Maltese innovation and a cognate of both $\breve{a}$ and $\breve{l}$;

b. ă and $\check{l}$ both shifted to the three short vowels $\breve{a}$, $\breve{~} \breve{i}$;

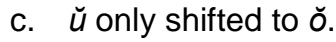

Thus, the Maltese evolution bears witness of a tendency to the fusion of ă and $\check{r}$ in one phoneme. David Cohen established the following laws of phonological change, which I reverse here to the perspective of their Maltese outcomes, and which concern only stressed vowels:

(1) The situation for Maltese /ö/is quite straightforward: it is cognate with Arabic *ŭ in almost all nominal and verbal forms; $\breve{u}$ only occurs scarcely as an optional allophone of /ö/ (David Cohen also notes that in non-accented position, ŭ sometimes became /ă/ or /ĕ/).

(2) Maltese /ĕ/is cognate with

- Arabic * $\check{~}$ when preceded or followed by an actual or former laryngeal, a pharyngeal, a velar or the uvular qâf (now pronounced as a glottal stop);

- Arabic *ă when in contact with the etymological laryngeal $h$, in monosyllabic forms, in dissyllabic verbal forms in closed syllables, in the $\mathrm{C}_{1} \mathrm{VC}_{2} \mathrm{a}$ verb pattern.

(3) Maltese $\pi /$ is cognate with

- Arabic * $\check{\text { in }}$ the context of non-back consonants, except in case of vowel harmony with /ŏ/;

- Arabic *ă in dissyllabic forms in open syllables, in verbs whose basic pattern was *CV̆CV̆C-, in verbo-nominal forms such as bídi 'beginning' (as opposed to béda 'he began'), in verbo-nominal prefixes (tíbkir, tíblit, míbrūm, etc.), and often, but not systematically in non-verbal forms in closed syllables (cf. bikri : bakri).

In other words, phonemic conditioning, morphology and analogy were the driving forces for the various phonemic shifts. But phonemic conditioning has often overridden morphological and analogical processes, and generally, the old *ă 
kept its vocalic quality when in contact with the former "emphatics", the velars, the uvular and the pharyngeals.

In connection with the vowel shifts that occurred in Maltese, David Cohen also noticed that in contact with the flap $r$, the vowel /ă/ has all three possible

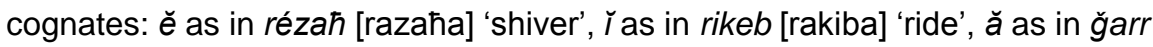
'drag, take away', just as with the other Maltese phonemes which are cognates with two phonemes, an emphatic and a non-emphatic one ( $s, t$ and $d)$. He concludes that, as in many Maghribi dialects but unlike classical Arabic, Maltese, at some stage of its development, had, in addition to the non-emphatic flap, an emphatic $r$ phoneme, as the case of ğarr which retained the original ă bears witness.

To sum up, in unstressed syllables, Arabic ă and $\check{I}$ have both evolved towards the vowel whose quality was imposed by the phonemic context, and with possible pharyngealization, vowel harmony, etc, and also by analogy with the morphological pattern of the form to which the vowel was assigned.

But the predominance of phonemic conditioning did not apply alike to all grammatical categories. David Cohen recalls that in a morphological system such as the verbal system, analogical and regularization factors are bound to play an important role which may go against phonological rules. One of them concerns the class of middle verbs in Arabic, usually an intransitive verb class. For instance the Maltese CVCC pattern in this verb category is characterized by a short vowel $e$, not an a, even when in contact with a back or a former

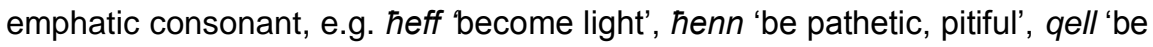
rude', se $\hbar \hbar$ 'be valid'. Another example is linked to the former fourth derived verb form, the one with a prefix Pa- in classical Arabic. In Maltese, the $\mathrm{CeCa}$ pattern includes verbs with a first back or emphatic consonant. Now, in many Maghribi varieties, there are a good number of pairs such as xla, yaxli 'he devastated': xla, yaxla 'he was ruined' which are differentiated by the vocalic opposition in final position after the second root consonant. This distinction goes back to the opposition between the causative fourth forms with the glottal stop prefix, and the middle form. Contemporary Maltese has only fossilized remnants of this fourth form, but it is remarkable that the verbs which in Maghribi Arabic are of the non-middle type like xla, yaxli all belong to the CeCa type in Maltese, whatever the root consonants, whereas the verbs which are of the type xla, yaxla with a back or an emphatic consonant in their roots, all belong to the type $\mathrm{CaCa}$. This can be illustrated by the opposition in Maltese between gera 'he run' and gara 'it took place' which corresponds to the Maghribi opposition between ğra, yağri and ğra, yağra, with a pharyngealized $r$.

So, once a phoneme is lost, phonological conditionings tend to lose ground and eventually cease to operate; morphological analogy can become more and 
more predominant, as is the case with the CoCoC pattern for middle verbs, which attracts other verbs of other patterns. But analogy and phonological conditioning did not occur simultaneously and exactly in the same way in all varieties of Maltese, and dialectal variation is still indicative of various stages in the phonological development of Maltese.

The vocalic cognate sets mentioned above are not the whole story and David Cohen showed that the vowels of the Maltese disyllabic pattern with two short vowels CV̆CV̆C do not all go back to former vowels. Some short vowels were introduced in order to disjoint consonant clusters with a sonorant, $I, r, r$ and $m$ as second element. Their quality is generally in harmony with the vowel characteristic of the pattern. Conversely, some of the former short vowels were eliminated: this was the case for disyllabic forms in the first syllable if the second syllable was long, in the second syllable if the initial consonant was a sonorant. In trisyllabic forms the second vowel was eliminated. David Cohen concludes this part of his article cautiously. He remarks that his data were not important enough to explain in details all the losses of short vowels and the role of the various influences that took place when consonant clusters were disjointed. Numerous forms remained unexplained and there is still fruit for further research.

However, as he states, the mechanism that triggered the shift from the old vocalic system to the Maltese system is clear. /ĕ/ as a phoneme distinct from $/ /$ / is in Maltese an interrupted evolution, which froze differences which were tending to be conditioned variants. The opposition between /ë/ and $\pi /$ / thus partly represents the former opposition between /ă/ and $/ /$.

As for the existence of a short and a long a (/ă/ : /ā/), it has a common explanation: the fusion of the "emphatic" consonant with the corresponding nonemphatic ones. The emphatic consonants had prevented the shift from /ă/ and $/ \bar{a} /$ to $/ \bar{e} /$ and $/ \bar{e} /$, but once they were lost, /ă/ and /ā/ became contextually independent. Variants became phonemes by a transfer of distinctive features from the consonants to the vowels.

\subsection{The imaala}

David Cohen also hypothesizes to a pre-Maltese stage, the existence of a high degree of what is traditionally termed imaala in Arabic grammars, that is the raising and fronting of the back vowel a/a towards $i / \bar{t}$ through an intermediate stage e/e, for both long and short vowels, except when the back vowel was in contact with the back and the emphatic consonants. David Cohen recognized that there were exceptions that needed to be accounted for and that were triggered by different processes such as analogy. This was done in Alexander 
Borg's (1976: 220) paper on the imaala in Maltese where he showed that "both vocalic and consonantal conditioning are likely to have played their part in the present-day situation", as well as analogy for some patterns where the imaala was "grammatically conditioned", and possibly the reintroduction of a new layer of Arabic variety at a later stage which counteracted the spread of the imaala even in conditioning contexts, a possibility which he qualifies as highly speculative.

It comes as a natural conclusion of all the previous arguments developed by David Cohen that the imaala paved the way to the posterior phonologisation of the opposition between $a$ and $e$, and that it necessarily preceded the loss of the emphatic consonants which occurred at a Maltese stage, just as, more recently, the general weakening of the back consonants triggered an opening of the adjacent closest vowels. But for $/ \breve{u} /$ the opening to /o/ occurred in all contexts.

\subsection{The Cantilena}

The above reconstruction of the phonological system of Maltese (together with other arguments) was used for a later joint research that we did in 1986, David Cohen and myself, on the famous Cantilena of Peter Caxaro, and which was published in 1991. We proposed some new interpretations of the text based on comparative, phonological, morphological, syntactic, philological, and stylistic criteria.

The analysis of the spelling system, even if not a systematic system, showed that the degree of evolution of the Maltese phonological system in the 15 th century was by far not as distant from its origins as it is today. Still it already showed at an incipient stage the signs of further evolutions. At that time, Maltese had preserved all the back consonants: the uvular $q$, the unvoiced fricative laryngeal $h$,the distinction between the voiced and unvoiced fricative velars $x$ and $\hbar$, and the pharyngeals and $\gamma$ and $\zeta$, even though the latter was already weak in final position. I could confirm later, in an article concerning the allophones of ghajn in the idiolect of an elderly speaker of the village of Mtahleb who had preserved the fricative pharyngeal articulation, that the weakest position was actually the final root position where ghajn was never pronounced as such (Vanhove 1991-1992).

There is no clear evidence in the spelling system of the Cantilena that the emphatic consonants were preserved at that time, but there are clear indications of their influence on the quality of the adjacent vowels. For example, it 
was possible to reconstruct for the word tale, a verb *tala 'go up' ( $<$ țalas), instead of taalin 'then' (a meaning not attested in Arabic) or talahawn 'come here' proposed by Wettinger (1978). "tala is semantically and stylistically more adequate than the two hypotheses he proposed. Cowan (1975) sees, may be cor-

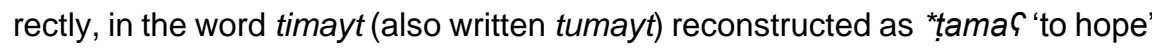
an indication that the emphatic consonants were still preserved. But it is possible that this word may go back to *ihtamma 'to worry about', since neither the $h$ nor the gemination are systematically noted in the Cantilena, and since the meaning is not incompatible with the context ('where I hoped to find stones' or 'where I was worried about stones'). Nevertheless, our translation followed Cowan's, but with caution.

At the phonetic level, the analysis of the Cantilena showed that (i) there was no neutralization yet between voiced and unvoiced consonants in final position (cf. ard); (ii) that the imaala was an already existing phenomenon, but not as strong as in today's standard Maltese (cf. gireni 'my neighbors'); (iii) that short $i$ had not disappeared in open syllables except in verbo-nominal forms with prefixes; (iv) that vowel harmony with $o$ was already pervasive.

The text of the Cantilena keeps part of its mystery: not all the problems could be solved, and not all our hypothesis were fully satisfying. Still the application of a rigorous comparative method, and concern about the semantic accuracy of the proposed etymons and their possible semantic shifts, as well as the syntax of the verses, were important to avoid the pitfalls of unlimited imagination. For instance in verse 5, hayran (< xayraan) does not mean 'willing, wanting' but 'embarrassed, troubled, worried', an adjective often found in love songs with the meaning of 'desperately in love'. Furthermore it is not a verbo-nominal form followed by its complement as Wettinger \& Fsadni (1968) suggest, but an adjective with a stative meaning. Similarly minzeli does not mean 'my fall' but literally 'the place where I go down, where I have to go', and in this context metaphorically, 'my destiny'. We thus proposed a very different translation: 'Where desperately in love, I go down the steps of my destiny in order to drown myself'.

\section{Conclusion}

After these papers, David Cohen did not go on working on Maltese himself. As a conclusion, I would like to acknowledge the fact that his influence on Maltese studies went far beyond the domain of phonology, at least as far as I am con- 
cerned, through his work on aspect, auxiliaries, and the morphogenesis of verbal systems. Regarding auxiliaries, David Cohen never managed to fully express his thoughts in the form of a book. But he started circulating his research on this topic in the early 1980's during his lectures at the Ecole Pratique des Hautes Etudes in Paris. These lectures were summarized and published in the annual reports of this institution, and are now freely available on line, thanks to Gilbert Puech's efforts, who for several years was the head of a vast enterprise, which digitalized a lot of French Academic work for the internet portal Persée (http://www.persee.fr/web/ouvrages/home/prescript/fond/ephe).

Later, part of David Cohen's approach of morphogenis was included in his book L'aspect verbal (1989)3, and more recently, in one of his last book published in 2006: Essais sur l'exercice du langage et des langues. Vol. 1: Communication et langage. Even if both are written in French, I strongly encourage everyone to read them.

\section{References}

Aquilina, Joseph. 1973 (1959). The structure of Maltese. Malta: The Royal University of Malta.

Borg, Albert \& Marie Azzopardi-Alexander. 1997. Maltese. London: Routledge.

Borg, Alexander. 1976. The Imaala in Maltese. Israel Oriental Studies 6. 191-223.

Borg, Alexander. 1977. Reflexes of pausal forms in Maltese rural dialects? Israel Oriental Studies 7. 211-225.

Borg, Alexander. 1996. On some Levantine linguistic traits in Maltese. Journal of Oriental Studies. Studies in Modern Semitic Languages 16. 133-152.

Brame, Michael K. 1972. On the abstractness of phonology: Maltese . In Michael K. Brame (ed.), Contributions to generative phonology, 22-62. Austin \& London: University of Texas Press.

Camilleri, Antoinette \& Martine Vanhove. 1994. A phonetic and phonological description of the Maltese dialect of Mgarr (Malta). Zeitschrift für arabische Linguistik 28. 87-110.

Cohen, David. 1957-1960. Sur le vocalisme du maltais. Comptes Rendus du G.L.E.C.S. 8. 83-85.

Cohen, David. 1963. Le dialecte arabe Hassānīya de Mauritanie. Paris: Klincksieck.

Cohen, David. 1964-1975. Le parler arabe des Juifs de Tunis. Tome 1: Textes et documents linguistiques et ethnographiques. Tome 2: Etude linguistique. La Haye/Paris: Mouton.

Cohen, David. 1970. Etudes de linguistique sémitique et arabe. La Haye/Paris: Mouton.

3 This became the framework of my own research on the verbal system of Maltese (Vanhove 1991, 1993, 2003; Vanhove \& Simeone-Senelle 1997). 
Cohen, David. 1970-99. Dictionnaire des racines sémitiques ou attestées dans les langues sémitiques comprenant un fichier comparatif de Jean Cantineau. 10 volumes. Paris/La Haye: Mouton and Paris: Maisonneuve et Larose.

Cohen, David. 1973-74. Résumé des conférences. Annuaire de l'Ecole Pratique des Hautes Etudes, IVe section. 175-191.

Cohen, David. 1983. Rapport 1982-1983. Les auxiliaires dans l'expression périphrastique du parfait. Annuaire de l'Ecole Pratique des Hautes Etudes, IVe section. 58-59.

Cohen, David. 1984. La phrase nominale et l'évolution du système verbal en sémitique. Étude de syntaxe historique. Leuven/Paris: Peeters.

Cohen, David. 1989. L'aspect verbal. Paris: Presses universitaires de France.

Cohen, David. 2006. Essais sur l'exercice du langage et des langues. Vol. 1: Communication et langage. Paris: Maisonneuve et Larose.

Cohen, David, Jean Dubois, Michel Gauthier, Henri Hecaen \& R. Angelergues. 1963. Aspects du fonctionnement du code linguistique chez les aphasiques moteurs. Neuropsychologia 1. 165-177.

Cohen, David \& Michel Gauthier. 1965. Aspects linguistiques de l'aphasie. L'Homme. Revue française d'anthropologie 5. 5-31.

Cohen, David \& Martine Vanhove. 1991. La cantilène maltaise du 15ème siècle: Remarques linguistiques. Comptes rendus du G.L.E.C.S. 29-30, 1984-1986 (conference of 19 March 1986). 177-220.

Cowan. 1966.

Cowan. 1975.

Firth, John Rupert. 1957. Papers in linguistics 1934-1951. London: Oxford University Press.

Heine, Bernd. 1993. Auxiliaries. Cognitive forces and grammaticalization. Oxford: Oxford University Press.

Lentin, Jérôme \& Antoine Lonnet (eds.) 2003. Mélanges David Cohen. Etudes sur le langage, les langues, les dialectes, les littératures, offertes par ses élèves, ses collègues, ses amis. Présentés à l'occasion de son quatre-vingtième anniversaire. Paris: Maisonneuve et Larose.

Puech, Gilbert. 1979. Les parlers maltais. Essai de phonologie polylectale. Thèse d'Etat. Université de Lyon II.

Puech, Gilbert. 1994. Ethnotextes maltais (Studia Melitensia 1). Wiesbaden: Harrassowitz.

Schabert, Peter. 1976. Laut- und Formenlehre des Maltesischen anhand zweier Mundarten. Erlangen: Palm \& Enke.

Stumme, Hans. 1904. Maltesische Studien. Eine Sammlung prosaischer und poetischer Texte in maltesischer Sprache nebst Erläuterungen. Leipzig, J.C. Hinrich'sche Buchhandlung, coll. Leipziger Semitische Studien, I, 4.

Sutcliffe, Edmund F. ${ }^{3} 1960$. (1936). A grammar of the Maltese language: with chrestomathy and vocabulary. La Valette: Progress Press.

Vanhove, Martine. 1991. L'expression du parfait en maltais. In Alan S. Kaye (ed.), Semitic studies in honor of Wolf Leslau on the occasion of his eighty-fitth birthday, November 14th, 1991. Vol. 2, 1601-1618. Wiesbaden: Harrassowitz.

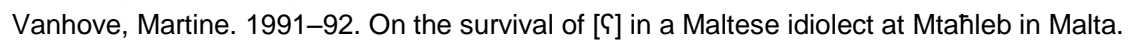
Journal of Afroasiatic Languages 3. 22-34.

Vanhove, Martine. 2003. Auxiliaires, grammaticalisation et transcatégorialité: Le cas des marqueurs de futur et d'injonction en maltais. In Stéphane Robert (ed.), Perspectives 
synchroniques sur la grammaticalisation. Polysémie, transcatégorialité et échelles syntaxiques, 149-162. Louvain/Paris: Peeters.

Vanhove, Martine \& Marie-Claude Simeone-Senelle. 1997. La formation et l'évolution d'auxiliaires et particules verbales dans des langues sémitiques: les langues sudarabiques modernes et le maltais. Mémoires de la Société de Linguistique de Paris. Grammaticalisation et Reconstruction. Nouvelle série 5. 85-102.

Wettinger, Geoffrey. 1978. Looking back on 'The Cantilena' of Peter Caxaro. Journal of Maltese Studies 12. 88-105.

Wettinger, Geoffrey \& Michael Fsadni. 1968. Peter Caxaro's Cantilena, a poem in Medieval Maltese. Malta. 